\begin{tabular}{|l|l|l||}
\hline \multicolumn{2}{|c|}{ PublisherInfo } \\
\hline \hline PublisherName & $:$ & BioMed Central \\
\hline \hline PublisherLocation & $:$ & London \\
\hline \hline PublisherImprintName & $:$ & BioMed Central \\
\hline \hline
\end{tabular}

\title{
AT targets for anti-tumor drugs
}

\begin{tabular}{||l|l|l||}
\hline \multicolumn{2}{|c|}{ ArticleInfo } \\
\hline \hline ArticleID & $:$ & 4288 \\
\hline \hline ArticleDOI & $:$ & $10.1186 /$ gb-2001-3-1-reports0002 \\
\hline \hline ArticleCitationID & $:$ & reports0002 \\
\hline \hline ArticleSequenceNumber & $:$ & 20 \\
\hline \hline ArticleCategory & $:$ & Paper report \\
\hline \hline ArticleFirstPage & $:$ & 1 \\
\hline \hline ArticleLastPage & $:$ & 4 \\
\hline \hline & & \\
\hline ArticleHistory & $:$ & Received $\quad:$ 2001-11-13 \\
\hline \hline ArticleCopyright & $:$ & BioMed Central Ltd2001 \\
\hline \hline ArticleGrants & $:$ & \\
\hline \hline ArticleContext & $:$ & 130593311 \\
\hline \hline
\end{tabular}




\section{Abstract}

Binding sites for the anti-tumor drug bizelesin in DNA are identified by in silico and in vitro analysis of AT-rich islands

\section{Significance and context}

Efficient targeting of DNA-reactive anti-tumor drugs is important for effective treatment and minimal side effects. A number of such drugs bind indiscriminately to multiple targets, including non-DNA ones, but some of the drugs that bind to the DNA minor groove show sequence specificity. The most promising of the sequence-specific drugs are bizelesin and adozelesin. Bizelesin is highly cytotoxic; it can form crosslinks or monoadducts with DNA and inhibits growth of target cells at low adduct concentrations. This is attributed to bizelesin's sequence-specific mode of action. It has been suggested that the target sequences are regions important for cell growth, and the AT-rich matrix-associated regions (MARs) have been proposed as a target, but the actual binding sites have not been identified. Woynarowski et al. have now combined bioinformatics and pharmacogenomics with molecular pharmacology to evaluate the ability of bizelesin to target specific sequences in the DNA, and they identify the bound sequences.

\section{Key results}

AT-islands are localized approximately $1 \mathrm{Mb}$ apart and the number of bizelesin-binding sites depends on the length of the island. Woynarowski et al.have identified 40 AT-islands, which included the loci Z79699, Z80771, X04682 (APOB gene), X00364 (c-MYC gene), AC005195, Z72519, Z82900 and two fragile sites, FRA16D and FRA16B. Sequence analysis showed that TATA boxes and polyadenylation sites outside the AT-islands were unlikely targets for bizelesin.

In silico analysis of the human genome revealed that potential bizelesin-target sites (MARS and ATrich minisatellites) are distributed non-randomly; they are localized in hot spots in which the density of the bizelesin-binding motifs is up to 99 hits per 250 basepairs (bp). In contrast, the density of the bizelesin-binding motifs in bulk DNA was only 2.8 hits per $250 \mathrm{bp}$ for the formation of the interstrand crosslinking sites $(\mathrm{T}(\mathrm{A} / \mathrm{T}) 4 \mathrm{~A})$, and 8.6 hits per $250 \mathrm{bp}$ for the monoadducts $(\mathrm{A}(\mathrm{A} / \mathrm{T}) 4 \mathrm{~A})$. Both motifs were found in the same loci but at different densities depending on the sequence of the DNA fragment. 
In addition to the in silico analysis, the authors present in vitro binding data on naked DNA and DNA from carcinoma cell lines. For example, PCR products for the Z79699 fragment were treated with bizelesin and the binding sites were identified by sequencing. These sites were in good agreement with the in silico predicted sites and no lesions were observed in non-AT-island loci or in bulk DNA. Analysis of the bizelesin-binding sites revealed that they are short repeat sequences arranged in various order with no common consensus in the repeat arrangement, their only common trait was high AT content. Analysis of DNA duplex stability within the islands revealed reduced thermodynamic stability over a significant length of DNA. These unstable duplexes correlated with lower DNA melting temperature $\left(T_{\mathrm{m}}\right)$, reduction of free energy $(G(\mathrm{x}))$ and high values of superhelical stress (SIDD). The high values of SIDD indicated that the AT-islands can remain unpaired under supercoiling stress. These regions were also found to be unusually flexible (with twisting movement over $16^{\circ}$ ) allowing for potential twisting of the DNA.

\section{Links}

The MAR sequence database used by the authors can be found at S/MARt DB - The S/MAR transaction DataBase. The FlexStab program, which calculates flexibility of DNA,can be obtained from the homepage of Kerem Batsheva and the MAR finder from Futuresoft's MAR-Wiz. TATA boxes and polyadenylation sites were identified using WebGene tools hosted by the Consiglio Nazionale dello Ricerche Istituto Tecnologie Biomedicho Avanzate. The online version of the paper (available to subscribers only) contains an extended list of over 40 prominent regions identified in this study.

\section{Conclusions}

Bizelesin binds DNA in a sequence-specific manner and induces lesions in naked DNA and in cellular DNA from carcinoma cell lines. The MAR-like AT-islands appear to be the primary target of bizelesin action.

\section{Reporter's comments}

The main aim of the authors - to show that sequence-specific targeting of the repetitive sequences is possible - has been achieved. The authors also established bizelesin-binding sites genome-wide and confirmed their binding in in vitro experiments. There are, however, unanswered questions as to whether all tumors respond to bizelesin in the same way or whether there are differences between tumor types. It will also be important to determine whether bizelesin induces breaks in DNA in normal cells. 


\title{
Table of links
}

\author{
Journal of Biological Chemistry \\ S/MARt DB - The S/MAR transaction DataBase \\ Kerem Batsheva \\ MAR-Wiz \\ WebGene

\section{References}

1. Woynarowski JM, Trevino AV, Rodriguez KA, Hardies SC, Benham CJ: AT-rich islands in genomic DNA as a novel target for AT-specific DNA-reactive antitumour drugs. J Biol Chem. 2001, 276:

40555-40566. 0021-9293

This PDF file was created after publication. 